\title{
Pecan Tree Growth and Precocity
}

\author{
T.E. Thompson ${ }^{1}$ and L.J. Grauke ${ }^{2}$ \\ Agricultural Research Service, U.S. Department of Agriculture, College Station, TX 77840
}

\begin{abstract}
Additional Index words. Carya illinoinensis
Abstract. Precocity of pecan [Carya illinoinensis (Wangenh.) C. Koch] seedlings (year of first fruit production) was studied in relation to original seed measurements (nut weight, buoyancy, volume, and density) and in relation to growth index (GI) measurements of seedling trees for 4 years. A total of 2,071 pecan seedlings, representing nine controlled-cross families, were studied. Original seed measurements were not related to precocity of resultant seedling trees; but seed weight, buoyancy, and volume were significantly correlated with seedling growth rates. Nut density was negatively related to growth of seedlings. These relationships show the importance of original seed measurements and seed parentage in determining seedling growth, and have direct relevance in pecan nursery operations to increase general rootstock seedling vigor. Seedling growth rate was significantly correlated to precocity levels, with measurements taken in the later years of the study showing the highest correlations with precocity. This strong growth-precocity relationship may have negative genetic implications since a common breeding objective is to produce more precocious cultivars that maintain smaller tree size in mature orchards.
\end{abstract}

The largest pecan [Carya illinoinensis (Wangenh.) C . Koch] breeding program in the world is operated by USDA-ARS, and is headquartered at two sites: College Station and Brownwood, Texas. In cooperation with various state agricultural experiment stations, 24 cultivars have been released from this program which began in 1931 (Grauke and Thompson, 1996; Thompson and Grauke, 1991). After controlled crosses are made, the trees are evaluated under field conditions, then the best clones are selected to be tested further in NPACTS (National Pecan Advanced Clone Testing System). In NPACTS, clones are vegetatively propagated and tested in major pecan production areas for specific environmental suitability as new cultivars. The average time from crossing to cultivar release for the 24 USDA and state cultivars is $\approx 27$ years (ranging from 13 to 60 years). Considering the year to make the controlled cross, the 10-year cycle for evaluation in the Basic Breeding Program (BBP), and the 9 to 15 year evaluation period in NPACTS, a development time of 20 years is realistic.

The system first developed by E.E. Risien (L.D. Romberg, personal communication), and later used routinely by L.D. Romberg in the USDA-ARS program, consists of budding 6 to 8 month old clones to large pollarded trees, and forcing the buds the following spring. This system shortens the BBP evaluation time $\approx 4$ years, since the clones flower at 4 to 6 years of age, compared to years 8 to 11 in the current breeding program where the clones are grown on their own roots in the $\mathrm{BBP}$. This program is used to some extent currently, but is more labor intensive.

Pecan also exhibits a xenia and metaxenia effect in that basic nut characteristics, such as nut weight, buoyancy, and number of fruit per cluster, are partially determined by pollen parent and the resultant embryo genotype (Romberg and Smith, 1949; Thompson and Brown, 1981). Almost all of the pecan kernel is embryo and thus a xenia effect is logically a manifestation of heterosis of the embryo. Since nut size is determined by fruit and shell (pericarp) size, which are both of maternal origin, this is a metaxenia effect. In all these studies, selfing was deleterious to general nut quality and seedling vigor. The pollen parent also affects time required for seed germination (Ou et al., 1994). We wondered if nut characteristics, which are partically determined by heterosis of the embryo, could be used to preselect for superior hybrid vigor. Any increased efficiency would be valuable for eliminating inferior seedlings that lack sufficient vigor to be released as new cultivars.

Received for publication 22 May 2002. Accepted for publication 24 Oct. 2002. ${ }^{1}$ Research geneticist.

${ }^{2}$ Research horticulturist.
Limited success has been obtained in developing an artificial method to induce pistillate flowers on juvenile clones in the second year of growth (Thompson, 1986). A 2-year generation time using this technique is a possibility. Presently this system is not efficient on large numbers of clones and must await further refinement before it can be routinely used in the BBP.

Also of concern is what level of precocity, vigor, and tree size are most desirable horticulturally. Romberg and Smith (1950) reported that hybrid vigor is desirable in pecan. Alben et al. (1953) showed that pecan cultivars differ for initial orchard growth. Persian walnut (Juglans regia L.), is a highly productive crop in California that offers a prototype for pecan genetics advancement. Current thinking in walnut is that maximum tree vigor (both rootstock and scion) is an absolute requirement for maximum production. Initial tree growth in walnut is rapid (faster than pecan), then scion growth is minimal during the mature tree phase, being limited by fruit production. This growth scenario seems ideal, since it contributes to early tree development, then stable production with reduced vegetative growth. These desirable genetic characteristics seem obtainable in pecan.

It has been generally known for many years that precocity is positively related to growth in seedling trees (Zimmerman 1972), but little information has been published on this relationship in pecan breeding programs. Breeding efficiency over years is strongly affected by generation time, especially in pecan. These experiments utilized records from the pecan breeding program to investigate this relationship and to refine and improve the efficiency of the USDAARS pecan breeding program.

\section{Materials and Methods}

Experiments were conducted using nine pecan families produced in the BBP at College Station, Texas (Table 1). The first two digits of the family number represent the year the controlled cross was made, the second number represents the cross, followed by the female parent and male parent. Controlled pollinations were made in April of each year as described by Smith and Romberg (1940). Nuts were hand harvested, dried at room temperature, and stored at $2{ }^{\circ} \mathrm{C}$ until nondestructively measured (nut weight, buoyancy, volume, and density). Nut buoyancy was determined by submerging individual nuts in a weighted screen container in water below a digital balance. The balance was supported by a wooden frame above a container of water. The difference in weight of the empty screen container suspended in the water and the decreased weight of the container with the nut submerged was buoyancy, measured in grams. Since water has a density of $1.0 \mathrm{~g} \cdot \mathrm{mL}^{-1}$, this buoyancy (in grams) was 
added to nut weight, and these changed to $\mathrm{mL}$ to determine nut volume. Nut density was determined by dividing weight by volume.

Nuts were then stratified for 6 weeks before planting in greenhouses in square plastic containers $(10 \times 10 \times 35 \mathrm{~cm}$ tall $)$ filled with a commercial mix (VitalEarth potting soil; VitalEarth Resources, Galdewater, Texas). After 1 year of growth in the greenhouse, bareroot dormant trees were transplanted to the field in Burleson County, Texas, in a Westwood silt loam soil, $0 \%$ to $1 \%$ slope (fine-silty, mixed, thermic Fluventic Ustochrepts). Tree spacing was $3 \times 4.6 \mathrm{~m}$, and trees received standard recommended culture and irrigation, except no fungicides were applied.

Growth measurements were recorded after the growing seasons of 1989, 1990, 1991, and 1993. For the years 1989 and 1990, trunk circumference $30 \mathrm{~cm}$ high was recorded on trees $>1 \mathrm{~m}$ tall. Tree height was recorded on trees less than $1 \mathrm{~m}$ tall. For the years 1991 and 1993, trunk circumference was taken at $1 \mathrm{~m}$ height on trees $>3$ $\mathrm{m}$ tall. Plant height was recorded on all trees $<3 \mathrm{~m}$ tall. A growth index (GI) was computed for trees measured during all 4 years. For the larger trees where circumference was recorded, cross-sectionalarea (CSA) was computed directly from the circumference measurement. For smaller trees, the starting point to determine GI was the CSA for the smallest trees for which circumference was determined. A percentage of this value was assigned, based upon tree height. For 1989 and 1990, the smallest CSA computed for circumference was $2 \mathrm{~cm}^{2}$. GI was determined by dividing height by 100 and multiplying this value by 2.0. Similarly, for 1991 and 1993, propor-

Table 1. Number of seedling trees producing their first pistillate flowers.

\begin{tabular}{|c|c|c|c|c|c|c|c|c|}
\hline \multirow[b]{3}{*}{ Family } & \multicolumn{6}{|c|}{ No. of seedling trees with pistillate flowers } & \multirow{3}{*}{$\begin{array}{c}\text { Never } \\
\text { flowered }\end{array}$} & \multirow{3}{*}{$\begin{array}{l}\text { Total } \\
\text { trees }\end{array}$} \\
\hline & \multicolumn{6}{|c|}{ Years } & & \\
\hline & 7 & 8 & 9 & 10 & 11 & 12 & & \\
\hline 86-2 Wichita x Pawnee & 0 & 0 & $78(15)^{z}$ & $9(2)$ & $43(8)$ & 0 & $392(75)$ & 522 \\
\hline 86-3 Cheyenne $x$ Pawnee & 0 & 0 & $192(38)$ & $14(3)$ & $95(19)$ & 0 & $202(40)$ & 503 \\
\hline 87-1 Cheyenne $x$ Pawnee & 0 & $8(8)$ & $6(6)$ & $13(13)$ & $1(1)$ & 19 (19) & $54(54)$ & 101 \\
\hline 87-2 Wichita x Johnson & 0 & $6(3)$ & $3(2)$ & $59(33)$ & $2(1)$ & $6(3)$ & $105(58)$ & 181 \\
\hline 88-1 Cherokee $\mathrm{x}$ Johnson & $20(6)$ & $5(1)$ & $113(32)$ & $4(1)$ & $41(12)$ & $6(2)$ & $164(46)$ & 353 \\
\hline 88-3 Cherokee x Creek & $4(5)$ & $1(1)$ & $17(23)$ & $5(7)$ & $21(28)$ & 0 & $27(36)$ & 75 \\
\hline 88-6 Wichita x Pawnee & $1(1)$ & $2(1)$ & $11(8)$ & $2(1)$ & $17(12)$ & $1(1)$ & $109(76)$ & 143 \\
\hline 88-7 Osage $x$ Pawnee & $1((2)$ & $2(3)$ & $2(3)$ & $1(2)$ & $1(2)$ & $4(7)$ & $47(81)$ & 58 \\
\hline 88-10 Wichita $\times$ Cherokee & $3(2)$ & $3(2)$ & $11(8)$ & $2(1)$ & $4(3)$ & $4(3)$ & $108(80)$ & 135 \\
\hline Total across years & $29(1)$ & $27(1)$ & $433(21)$ & $109(5)$ & $225(11)$ & $40(2)$ & $1208(59)$ & 2071 \\
\hline
\end{tabular}

zercentage of the total number of seedling trees in the family.

Table 2. Pearson correlation coefficients $(r)(\mathrm{n}=863)$ and statistical probabilities for original seed measurements and precocity and growth indexes for all clones of all families that produced pistillate flowers through age 12 years.

\begin{tabular}{|c|c|c|c|c|c|c|c|c|}
\hline Parameter & $\begin{array}{c}\text { Nut } \\
\text { wt } \\
(\mathrm{g})\end{array}$ & $\begin{array}{c}\text { Nut } \\
\text { buoyancy } \\
(\mathrm{g})\end{array}$ & $\begin{array}{c}\text { Nut } \\
\text { vol } \\
(\mathrm{mL})\end{array}$ & $\begin{array}{c}\text { Nut } \\
\text { density } \\
\left(\mathrm{g} \cdot \mathrm{mL}^{-1}\right)\end{array}$ & $\begin{array}{c}\text { Growth } \\
\text { index } \\
(1989)\end{array}$ & $\begin{array}{c}\text { Growth } \\
\text { index } \\
(1990)\end{array}$ & $\begin{array}{c}\text { Growth } \\
\text { index } \\
(1991)\end{array}$ & $\begin{array}{c}\text { Growth } \\
\text { index } \\
(1993)\end{array}$ \\
\hline Precocity & $-0.055^{\mathrm{NS}}$ & $-0.021^{\mathrm{NS}}$ & $-0.050^{\mathrm{NS}}$ & $0.009^{\mathrm{NS}}$ & $-0.144^{* * *}$ & $-0.179^{* * *}$ & $-0.198^{* * *}$ & $-0.347^{* * *}$ \\
\hline Nut weight (g) & & $0.471^{* *}$ & $0.944^{* *}$ & $-0.113^{* *}$ & $0.329^{* * *}$ & $0.381^{* *}$ & $0.313^{* *}$ & $0.307^{* *}$ \\
\hline Nut buoyancy (g) & & & $0.735^{* *}$ & $-0.917^{* *}$ & $0.251^{* *}$ & $0.260^{* *}$ & $0.198^{* * *}$ & $0.234^{* *}$ \\
\hline Nut volume (mL) & & & & $-0.430^{* *}$ & $0.346^{* *}$ & $0.389^{* *}$ & $0.314^{* *}$ & $0.323^{* *}$ \\
\hline Nut density $\left(\mathrm{g} \cdot \mathrm{mL}^{-1}\right)$ & & & & & $-0.161^{* *}$ & $-0.150^{* *}$ & $-0.115^{* *}$ & $-0.162^{* *}$ \\
\hline Growth index (1989) & & & & & & $0.916^{* *}$ & $0.873^{* * *}$ & $0.759^{* * *}$ \\
\hline Growth index (1990) & & & & & & & $0.909^{* *}$ & $0.830^{* *}$ \\
\hline Growth index (1991) & & & & & & & & $0.857^{* *}$ \\
\hline
\end{tabular}

$\overline{\mathrm{Ns}, * *}$ Nonsignificant or significant at $P \leq 0.01$, respectively.

Table 3. Pearson correlation coefficients $(r)$ and statistical probabilities for precocity and original nut characteristics and growth indexes of different pecan cross families.

\begin{tabular}{|c|c|c|c|c|c|c|c|c|c|}
\hline Family & $\begin{array}{c}\text { No. } \\
\text { of } \\
\text { trees }\end{array}$ & $\begin{array}{l}\text { Nut } \\
\text { wt } \\
(\mathrm{g})\end{array}$ & $\begin{array}{c}\text { Nut } \\
\text { buoyancy } \\
(\mathrm{mL})\end{array}$ & $\begin{array}{c}\text { Nut } \\
\text { vol } \\
(\mathrm{mL})\end{array}$ & $\begin{array}{c}\text { Nut } \\
\text { density } \\
\left(\mathrm{g} \cdot \mathrm{mL}^{-1}\right)\end{array}$ & $\begin{array}{c}\text { Growth } \\
\text { index } \\
(1989)\end{array}$ & $\begin{array}{c}\text { Growth } \\
\text { index } \\
(1990)\end{array}$ & $\begin{array}{c}\text { Growth } \\
\text { index } \\
(1991)\end{array}$ & $\begin{array}{c}\text { Growth } \\
\text { index } \\
(1993)\end{array}$ \\
\hline 86-2 Wichita $\times$ Pawnee & 130 & $-0.216^{*}$ & $0.076^{\mathrm{NS}}$ & $-0.175^{*}$ & $-0.145^{\mathrm{NS}}$ & $-0.322^{* * *}$ & $-0.393^{* * *}$ & $-0.427^{* * *}$ & $-0.418^{* * *}$ \\
\hline 86-3 Cheyenne $x$ Pawnee & 301 & $-0.039^{\mathrm{NS}}$ & $0.092^{\mathrm{NS}}$ & $0.003^{\mathrm{NS}}$ & $-0.122^{*}$ & $-0.320^{\text {** }}$ & $-0.466^{* *}$ & $-0.402^{\text {** }}$ & $-0.551^{* *}$ \\
\hline 87-1 Cheyenne $x$ Pawnee & 47 & $-0.009^{\mathrm{NS}}$ & $0.147^{\mathrm{NS}}$ & $0.029^{\mathrm{NS}}$ & $-0.163^{\mathrm{NS}}$ & $-0.505^{* *}$ & $-0.375^{\text {*** }}$ & $-0.485^{\text {*** }}$ & $-0.548^{* * *}$ \\
\hline 87-2 Wichita x Johnson & 76 & $0.133^{\mathrm{NS}}$ & $0.057^{\mathrm{NS}}$ & $0.149^{\mathrm{NS}}$ & $-0.016^{\mathrm{NS}}$ & $-0.237^{*}$ & $-0.212^{\mathrm{NS}}$ & $-0.346^{* *}$ & $-0.386^{* *}$ \\
\hline 88-1 Cherokee $\mathrm{x}$ Johnson & 189 & $0.024^{\mathrm{NS}}$ & $-0.226^{* *}$ & $-0.090^{\mathrm{NS}}$ & $0.224^{* * *}$ & $-0.057^{\mathrm{NS}}$ & $-0.309^{* *}$ & $-0.389^{* * *}$ & $-0.607^{* *}$ \\
\hline 88-3 Cherokee x Creek & 48 & $-0.034^{\mathrm{NS}}$ & $-0.069^{\mathrm{Ns}}$ & $-0.052^{\mathrm{NS}}$ & $0.040^{\mathrm{NS}}$ & $-0.160^{\mathrm{NS}}$ & $-0.460^{* * *}$ & $-0.587^{* *}$ & $-0.632^{* *}$ \\
\hline 88-6 Wichita x Pawnee & 34 & $-0.071^{\mathrm{NS}}$ & $0.159^{\mathrm{NS}}$ & $0.001^{\mathrm{NS}}$ & $-0.166^{\mathrm{NS}}$ & $-0.160^{\mathrm{NS}}$ & $-0.281^{\mathrm{NS}}$ & $-0.455^{* *}$ & $-0.627^{* *}$ \\
\hline 88-7 Osage x Pawnee & 11 & $0.068^{\mathrm{NS}}$ & $0.098^{\mathrm{NS}}$ & $0.084^{\mathrm{NS}}$ & $-0.056^{\mathrm{NS}}$ & $-0.141^{\mathrm{NS}}$ & $-0.403^{\mathrm{NS}}$ & $-0.441^{\mathrm{NS}}$ & $-0.624^{*}$ \\
\hline 88-10 Wichita $x$ Cherokee & 27 & $0.045^{\mathrm{NS}}$ & $0.069^{\mathrm{NS}}$ & $0.056^{\mathrm{NS}}$ & $-0.048^{\mathrm{NS}}$ & $-0.062^{\mathrm{NS}}$ & $-0.334^{\mathrm{NS}}$ & $-0.349^{\mathrm{NS}}$ & $-0.378^{\mathrm{NS}}$ \\
\hline
\end{tabular}

$\overline{\mathrm{Ns}, *, * *}$ Nonsignificant or significant at $P \leq 0.05$, and 0.01 , respectively. 
tion of the 3 m height was determined, and multiplied by the smallest tree for which CMS was determined $\left(12 \mathrm{~cm}^{2}\right)$.

All trees were checked for fruit production as the trees matured. All nuts (up to 20) were harvested and standard BBP nut quality parameters determined. Tree age at the time of first fruit production was used as a measure of precocity, with the first year in the greenhouse counted. The GLM and other procedures of SAS (SAS Inst. Inc., Cary, N.C.) were used in all statistical tests.

\section{Results and Discussion}

Precocity, measured as year of first fruit production, was disappointing (Table 1). Overall, only $41 \%$ of the seedling trees had produced fruit by the end of the $12^{\text {th }}$ year. First fruit production was in year seven, with only $1 \%$ of the trees fruiting. The most trees flowered in the ninth year, about one in five. From general experience and various NPACTS yield tests (Thompson et al., 1981, 1983, 1989), the authors rate the genetic level of precocity of some of these parents very high. For instance, 'Cherokee' is unexcelled for precocity of first fruit production. All of the parents could be rated most to least precocious in the following order: 'Cherokee', 'Cheyenne', 'Creek', 'Wichita', 'Pawnee', 'Osage', and 'Johnson'. In the two full-sib families of 'Wichita' $x$ 'Pawnee', the results were fairly consistent in that $\approx 75 \%$ of the seedling trees never flowered through the $12^{\text {th }}$ year. As a parent, 'Cherokee' induced the greatest amount of precocity, even when crossed with the nonprecocious 'Johnson'. Further tests are needed to determine whether a cytoplasmic effect is exemplified in 'Cherokee' crosses. The crosses 88-1 and 88-3, where 'Cherokee' was the female parent and thus the cytoplasm donor to the progeny, were highly precocious. Conversely, in cross $88-10,80 \%$ of the progeny never flowered.

Precocity as Related TO ORIGINAL CROSS NUT MEASUREMENTS. All the correlations between precocity and the four nut variables were nonsignificant in the combined test (Table 2). These patterns were generally true within specific families (Table 3), although there were exceptions. For instance, precocity was negatively related to nut weight in cross 86-2, negatively related to buoyancy in cross 88-1, and negatively related to nut volume in $86-2$. Also, nut density was negatively related to precocity in cross $86-3$ and positively related to precocity in cross 88-1. Specific values are given for family 88- 1 in Table 4 , and the correlations for this family in Table 5. This family is presented in more detail since it had the greatest variability for precocity classes across years (Table 1). Nut weight showed overall significance between the precocity classes (year of first pistillate flower production), but the duncan's test showed no class differences. The same pattern was generally true for the other three nut characteristics. The standard deviation for the different precocity classes within families was high, also indicating little association.

The lack of a logical pattern across different precocity classes, coupled with the nonsignificance in the other tests discussed above, make it obvious that selection for seed-nut characteristics to affect the level of precocity among families is not a viable option. The xenia effect was probably present within the crosses, but its general weak expression, and lack of genetic linkage with precocity, prevents its utility as an indicator of precocity.

Correlations among these four nut parameters for all seedlings, and specifically for family 88-1 (Tables 2 and 5), were generally consistent with earlier results (Thompson et al., 1989). Nut volume was positively related to nut weight and buoyancy, and nut density was negatively related to buoyancy and volume. Nut weight and buoyancy were positively related in the earlier study and for combined analysis here, but unrelated for specific family 88-1. A limited number of
Table 4. Original nut measurements and growth indexes as related to the precocity of seedling trees in family $88-1$.

\begin{tabular}{|c|c|c|c|c|}
\hline Age $\left(\mathrm{N}^{\mathrm{z}}\right)$ & Minimum & Maximum & SD & Mean \\
\hline \multicolumn{5}{|l|}{ Nut $w^{*}(g)$} \\
\hline $7(20)$ & 5.16 & 7.46 & 0.63 & $6.25 \mathrm{a}^{\mathrm{y}}$ \\
\hline $8(5)$ & 5.07 & 7.44 & 0.97 & $6.61 \mathrm{a}$ \\
\hline $9(113)$ & 4.60 & 8.13 & 0.69 & $6.39 \mathrm{a}$ \\
\hline $10(4)$ & 5.60 & 6.68 & 0.49 & $6.20 \mathrm{a}$ \\
\hline $11(41)$ & 5.05 & 8.08 & 0.71 & $6.33 \mathrm{a}$ \\
\hline $12(6)$ & 5.92 & 7.24 & 0.52 & $6.57 \mathrm{a}$ \\
\hline $\mathrm{NF}^{\mathrm{x}}(164)$ & 3.87 & 8.05 & 0.78 & $6.08 \mathrm{a}$ \\
\hline \multicolumn{5}{|c|}{ Nut buoyancy* (g) } \\
\hline 7 & 0.55 & 2.14 & 0.42 & $1.14 \mathrm{a}$ \\
\hline 8 & 0.48 & 1.10 & 0.23 & $0.84 \mathrm{ab}$ \\
\hline 9 & 0.20 & 2.09 & 0.37 & $1.07 \mathrm{ab}$ \\
\hline 10 & 0.50 & 0.82 & 0.16 & $0.66 \mathrm{~b}$ \\
\hline 11 & 0.04 & 1.97 & 0.38 & $0.82 \mathrm{ab}$ \\
\hline 12 & 0.78 & 1.36 & 0.26 & $1.05 \mathrm{ab}$ \\
\hline NF & 0.24 & 2.97 & 0.50 & $1.04 \mathrm{ab}$ \\
\hline \multicolumn{5}{|c|}{ Nut volume* (mL) } \\
\hline 7 & 6.45 & 8.73 & 0.65 & $7.39 \mathrm{a}$ \\
\hline 8 & 5.97 & 8.36 & 1.02 & $7.45 \mathrm{a}$ \\
\hline 9 & 5.45 & 9.29 & 0.81 & $7.45 \mathrm{a}$ \\
\hline 10 & 6.36 & 7.50 & 0.50 & $6.86 \mathrm{a}$ \\
\hline 11 & 5.93 & 8.79 & 0.77 & $7.15 \mathrm{a}$ \\
\hline 12 & 6.89 & 8.08 & 0.47 & $7.62 \mathrm{a}$ \\
\hline NF & 4.66 & 8.90 & 0.88 & $7.12 \mathrm{a}$ \\
\hline \multicolumn{5}{|c|}{ Nut density ${ }^{*}\left(\mathrm{~g} \cdot \mathrm{mL}^{-1}\right)$} \\
\hline 7 & 0.73 & 0.92 & 0.05 & $0.85 \mathrm{~b}$ \\
\hline 8 & 0.85 & 0.93 & 0.32 & $0.89 \mathrm{ab}$ \\
\hline 9 & 0.72 & 0.96 & 0.05 & $0.86 \mathrm{ab}$ \\
\hline 10 & 0.88 & 0.93 & 0.02 & $0.90 \mathrm{a}$ \\
\hline 11 & 0.77 & 0.99 & 0.05 & $0.89 \mathrm{ab}$ \\
\hline 12 & 0.82 & 0.90 & 0.03 & $0.86 \mathrm{ab}$ \\
\hline NF & 0.62 & 0.96 & 0.06 & $0.86 \mathrm{ab}$ \\
\hline \multicolumn{5}{|c|}{ Growth index for $1989^{\mathrm{NS}}$} \\
\hline 7 & 0.18 & 0.60 & 0.60 & 0.36 \\
\hline 8 & 0.14 & 0.38 & 0.10 & 0.28 \\
\hline 9 & 0.04 & 0.68 & 0.13 & 0.32 \\
\hline 10 & 0.18 & 0.42 & 0.12 & 0.32 \\
\hline 11 & 0.12 & 0.54 & 0.11 & 0.33 \\
\hline 12 & 0.16 & 0.54 & 0.15 & 0.29 \\
\hline NF & 0.02 & 0.66 & 0.13 & 0.29 \\
\hline \multicolumn{5}{|c|}{ Growth index for $1990^{* *}$} \\
\hline 7 & 0.50 & 1.28 & 0.21 & $0.77 \mathrm{a}$ \\
\hline 8 & 0.60 & 0.80 & 0.08 & $0.70 \mathrm{ab}$ \\
\hline 9 & 0.14 & 1.66 & 0.26 & $0.67 \mathrm{ab}$ \\
\hline 10 & 0.50 & 0.86 & 0.15 & $0.67 \mathrm{ab}$ \\
\hline 11 & 0.26 & 0.86 & 0.15 & $0.55 \mathrm{bc}$ \\
\hline 12 & 0.12 & 0.72 & 0.21 & $0.45 \mathrm{c}$ \\
\hline NF & 0.02 & 0.92 & 0.18 & $0.45 \mathrm{c}$ \\
\hline \multicolumn{5}{|c|}{ Growth index for $1991^{* *}$} \\
\hline 7 & 1.40 & 8.95 & 2.04 & $3.66 \mathrm{a}$ \\
\hline 8 & 1.60 & 2.90 & 0.49 & $2.06 \mathrm{bc}$ \\
\hline 9 & 0.22 & 7.65 & 1.55 & $2.41 \mathrm{~b}$ \\
\hline 10 & 0.96 & 4.90 & 1.71 & $2.53 \mathrm{~b}$ \\
\hline 11 & 0.60 & 4.40 & 0.70 & $1.47 \mathrm{bc}$ \\
\hline 12 & 0.52 & 1.50 & 0.41 & $1.12 \mathrm{c}$ \\
\hline NF & 0.14 & 4.90 & 0.74 & $1.05 \mathrm{c}$ \\
\hline \multicolumn{5}{|c|}{ Growth index for $1993^{* *}$} \\
\hline 7 & 28.73 & 81.49 & 15.66 & $47.75 \mathrm{a}$ \\
\hline 8 & 28.73 & 53.79 & 9.98 & $38.31 \mathrm{ab}$ \\
\hline 9 & 6.25 & 81.49 & 16.86 & $32.50 \mathrm{bc}$ \\
\hline 10 & 8.25 & 58.01 & 23.40 & $23.91 \mathrm{~cd}$ \\
\hline 11 & 3.75 & 28.73 & 6.01 & $8.92 \mathrm{e}$ \\
\hline 12 & 7.25 & 25.78 & 7.88 & $16.11 \mathrm{de}$ \\
\hline NF & 0.40 & 62.39 & 12.41 & $10.29 \mathrm{e}$ \\
\hline
\end{tabular}

Ns, ${ }^{* * *}$ Nonsignificant or significant at $P \leq 0.05$, and 0.01 , respectively.

${ }^{\mathrm{z} N u m b e r}$ of trees.

'Means within each variable followed by the same letter are not significant by Duncan's multiple range test at $P \leq 0.05$.

${ }^{\mathrm{x}}$ Never flowered. 
Table 5. Pearson correlation coefficients $(r)(\mathrm{n}=189)$ of precocity with other characteristics of the cross $88-1$ ('Cherokee' $\mathrm{x}$ 'Johnson') at College Station, Texas.

\begin{tabular}{|c|c|c|c|c|c|c|c|c|}
\hline Parameter & $\begin{array}{l}\text { Nut } \\
\text { wt } \\
(\mathrm{g})\end{array}$ & $\begin{array}{c}\text { Nut } \\
\text { buoyancy } \\
\text { (g) }\end{array}$ & $\begin{array}{l}\text { Nut } \\
\text { vol } \\
(\mathrm{mL})\end{array}$ & $\begin{array}{c}\text { Nut } \\
\text { density } \\
\left(\mathrm{g} \cdot \mathrm{mL}^{-1}\right)\end{array}$ & $\begin{array}{l}\text { Growth } \\
\text { index } \\
(1989)\end{array}$ & $\begin{array}{l}\text { Growth } \\
\text { index } \\
(1990)\end{array}$ & $\begin{array}{l}\text { Growth } \\
\text { index } \\
(1991)\end{array}$ & $\begin{array}{c}\text { Growth } \\
\text { index } \\
\text { (1993) }\end{array}$ \\
\hline$\overline{\text { Precocity }}$ & $0.024^{\mathrm{NS}}$ & $-0.226^{* *}$ & $-0.090^{\mathrm{NS}}$ & $0.224^{* *}$ & $-0.057^{\mathrm{NS}}$ & $-0.309^{* *}$ & $-0.389^{* *}$ & $-0.607^{\text {*** }}$ \\
\hline Nut weight (g) & & $-0.002^{\mathrm{NS}}$ & $0.870^{* *}$ & $0.262^{* *}$ & $0.049^{\mathrm{NS}}$ & $0.016^{\mathrm{NS}}$ & $-0.000^{\mathrm{NS}}$ & $-0.000^{\mathrm{Ns}}$ \\
\hline Nut buoyancy (g) & & & $0.491^{* * *}$ & $-0.960^{* *}$ & $0.036^{\mathrm{NS}}$ & $-0.032^{\mathrm{NS}}$ & $-0.027^{\mathrm{Ns}}$ & $0.180^{*}$ \\
\hline Nut volume (mL) & & & & $-0.244^{*}$ & $0.060^{\mathrm{NS}}$ & $-0.002^{\mathrm{NS}}$ & $-0.023^{\mathrm{NS}}$ & $0.071^{\mathrm{Ns}}$ \\
\hline Nut density $\left(\mathrm{g} \cdot \mathrm{ml}^{-1}\right)$ & & & & & $-0.029^{\mathrm{NS}}$ & $0.026^{\mathrm{NS}}$ & $0.021^{\mathrm{NS}}$ & $-0.189^{* *}$ \\
\hline Growth index (1989) & & & & & & $0.461^{* *}$ & $0.205^{* *}$ & $0.186^{* *}$ \\
\hline Growth index (1990) & & & & & & & $0.761^{* *}$ & $0.630^{* *}$ \\
\hline Growth index (1991) & & & & & & & & $0.745^{* *}$ \\
\hline
\end{tabular}

,*,*** Nonsignificant or significant at $P \leq 0.05$, and 0.01 , respectively.

observations for this specific family probably accounts for this disparity.

TreE GROWTH AS RELATED TO ORIGINAL CROSS NUT MEASUREMENTS. The relationship of the four nut characteristics with seedling growth index was determined in a combined test of all flowering seedlings across all families (Table 2). Nut weight, buoyancy, and volume were positively related to all four GI measurements, while nut density was negatively related to the GI measurements. Normally high buoyancy and low density are associated with inferior nut quality, and could indicate low xenia effects and be expected to produce low seedling growth rates. Here it appears that larger nut size determined vigor, and larger nuts had associated larger buoyancies, and lower densities. Individual correlations within the nine families (data not shown) showed few significant correlations, which emphasizes the importance of parental effects. The association of nut quality and family on seedling vigor show the importance of seedling parentage and individual seed selection to maximize seedling vigor in routine pecan nursery operations.

Precocity as related to tree growth. There was tremendous variability for tree growth within and among families. Family 88-1 again is used as an example of growth variation (Table 4). For instance, in the 1993GI measurements, tree size varied from 0.4 to over $80 \mathrm{~cm}^{2} \mathrm{CSA}$. The standard deviations for all growth measurements were generally high as expected. Correlation values of precocity with the GIs for combined families were always negative and highly significant (Table 2). Negative relationships indicate that larger trees had a higher tendency to produce pistillate flowers at younger ages. The strength of the linear association between tree size and precocity increased in each succeeding year, giving greater validity to this relationship, which is common in many species (Zimmerman, 1972). In the example 88-1 family (Table 5), the 1989GI association was nonsignificant, but the other three GI measurements were highly significant, and they increased to -0.61 . Thus the GI in this family accounted for over one-third of the variability for precocity $\left(r^{2}=0.37\right)$. Variability within families was evident (Table 3), but always negative, showing that larger trees were more likely to produce fruit earlier. For 1989GI measurements, only four of nine $r$ values were significant, while all 1993GI values for all families were significant. Within 1993GI measurements for the different families, the proportion of precocity variability attributable to growth varied from $\approx 14 \%$ to $40 \%$.

Simple regression analyses were performed on the combined measurements of all families (data not shown). These formulae showed good agreement with above statistical relationships in that the later growth measurements showed stronger relationships of precocity with tree size. Simple regressions for the four field measurements for family 88-1 showed a much higher correlation (data not shown). As above, the correlation values increased as tree age in the field increased. The trees should have expressed their ability to flower, as determined by precocity phenotype before tree crowding and foliage competition was a factor.

GENETIC IMPLICATIONS OF ALL MEASUREMENTS. Pecan tree growth presents a true dichotomy for the pecan breeder and commercial grower. Strong growth is an obvious requirement in young orchards, and largely determines profitability of young orchards, since productivity is largely a function of tree size. Conversely, as trees mature, excessive growth produces crowding and is a liability. This often results in unthrifty orchards, which require some form of tree or limb removal to maintain production and nut quality. Pecan has evolved in a riverine environment, where survival was dependent upon its continual growth and dominance to maintain canopy. Thus commercial growers, by default, are left with this genetic characteristic that has to be managed as successfully as possible to maximize production and nut quality.

\section{Literature Cited}

Alben, A.O., B.G. Sitton, F.N. Dodge, and O.W. Harris. 1953. Comparative growth and yield of 'Stuart', 'Success', and 'Schley' pecan varieties. Proc. Amer. Soc. Hort. Sci. 61:307310

Grauke, L.J. and T.E. Thompson. 1996. Pecans and hickories, p. 185-239. In: J.A. Janick and J.N. Moore (eds.). Fruit breeding. vol. 3. Nuts. Wiley and Sons, New York.

Ou,Shyi-Kuan, J.B. Storey, and T.E. Thompson. 1994. A northern pecan pollen source delays germination of nuts from a southern pecan cultivar. HortScience 29:1290-1291.

Romberg, L.D. and C.L. Smith. 1949. Effect of cross-pollination, self-pollination, and sibpollination on the dropping, the volume and the kernel development of pecan nuts and on the vigor of the seedlings. J. Amer Soc. Hort. Sci. 47:130-138.

Romberg, L.D. and C.L. Smith. 1950. Progress report on the breeding of new pecan varieties. Proc. Texas Pecan Growers Assn. 29:12-21.

Smith C.L. and L.D. Romberg. 1940. Stigma receptivity and pollen shedding in some pecan varieties. J. Agr. Res. 60:551-564.

Thompson, T.E. 1986. Induction of pistillate flowers on juvenile pecan clones. HortScience 21:528-529.

Thompson, T.E. and E.J. Brown. 1981. Increased production and nut quality due to the xenia effect in pecan. Proc. S.E. Pecan Growers Assn. 74:145-148.

Thompson, T.E. and L.J. Grauke. 1991. Pecans and other hickories (Carya), p. 839-904. In: J.N. Moore and J.R. Ballington (eds.). Genetic resources of temperate fruit and nut crops. Intl. Soc. Hort. Sci., Wageningen, The Netherlands.

Thompson, T.E., R.E. Hunter, G.D. Madden, and E.J. Brown. 1981. Performance of varieties and selections in a high density orchard establishment test. Pecan Quart. 15:14-19.

Thompson, T.E. and R.E. Hunter. 1983. Further yield results from the Brownwood variety test. Pecan Quart. 17:13-19.

Thompson, T.E., E.F. Young, Jr., and W.O. McIlrath. 1989. Pecan nut and kernel characteristics show genotype-environment interacations. J. Amer Soc. Hort. Sci. 114:706-711.

Zimmerman, R.H. 1972. Juvenility and flowering in woody plants: A review. HortScience 7:447-455. 